\title{
HISTORY OF MARSHALL COUNTY.
}

BY NETTIE SANFORD, MARSHALLTOWN, IOWA.

(Continued from page 375.)

Hon. Wells S. Rice, formerly from Sandusky, Ohio, now the present Senator from this District to the Iowa Legislature, was one of the earliest settlers of Marshall County, and being identified with many of the enternrises connected with its prosperity, the historian must occasionally turn biographer through these pages. Perhaps there are few men in the State that have the pertinacity and untiring energies of Rice, Anson and Hon. G. M. Woodbury, who came a little later in $\mathbf{1 8 5 4}$ from Peora, Illinois. These three men, appreciating the natural advantages of Marshalltown over Marietta for a town, were determined to overthrow their rival, and make Marietta give up the county seat. For seven years the standing bone of contention, it was the occasion of quarrels all over the county-swapping, bargaining positions, and every other chicanery was resorted to, until in 1860 victory crowned their efforts and their work was aone.

Marietta, despoiled and dismantled, her Court House gone, stores removed, she only fills a place in history, instead of being the center of trade and enterprise, like her rival. Emigration came in freely in 1853-4 all over the beautiful lands.of the county, especially near the forests.

Friends with their sweet Quaker wives, tow-headed children from Indiana with their sickly mothers from the Wabash still shaking with the terrible "ager;" emigrants from Ohio and New York, with a sprinkling of Yankees, Dutch, etc. Land was cheap, the currency was gold and silver, and if a farmer raised anything he could sell it at a high price and improve his surroundings.

The year 1853 was a good one for farmers, - the great draw. back to settlers was the distance to market for building 
matcrial. Pine lumber had to be hauled from the Mississipi, for the one saw mill could not supply the settlers even with Iowa lumber from the native forests. Jack Braddy built a house from poles about as large as a stove pipe, "covering the roof with slough grass, with the bare earth for a floor, and a dry goods box for a pantry. A flour barrel held the library and wardrobe of the family, with the exception of their every day apparel. It used to be said that clothing would not wear in the Iowa winds as it did in the East. And no wonder. The drapery blowing about catching on the hazel brush and prairie weeds, and the supply of dry goods rather seant, it was not strange that careful mothers worried over these annoyances, besides the black mud which grimed and soiled everything about the home.

Many a poor emigrant mother, heart-broken and diseouraged, laid her brown hands across the tired breast to rest under the black Iowa soil, which had finally gained the victory in her everyday conflicts with it. Mrs. Dr. "Whealen, formerly of Marietta, tells us that she managed to entertain twenty-two persons in her little eabin one night. The room was about fifteen feet square, the cradle, chairs and table were set out of doors, and down upon the puncheon floors were placed the beds and quilts for the occupants. An over-coat, a dress or two, served as a partition to screen the girl sleepers from the rough emigrants that had come in that day to find homes.

Some of these girls now sleep in frescoed chambers, with rich upholstery, honored matrons receiving guests from all parts of the world in luxury and comfort. What a contrast from the early days!

Dr. Whealen, one of the best physicians in the vicinitr, was also a cabinet maker, so that he made the furniture for his little cabin. Three legged stools, pole bedsteads, a shoe box metamorphosed into a cradle, rough cotton-wood shelves and brackets, are among the monuments of his genius in that line. Dr. Whealen and Dr. Nixon, of Marietta, were the first 
physicians in the county. And such stories of exposure in crossing streams without bridges in the wild, stormy nights, of the snowy prairies where men were liable to be lost in the white waste, and sleep the sleep that knows no waking.

Many of the emigrants were too poor to pay a doctor's bill, or else canceled the indebtedness with a sick calf or a basket of geese eggs. Old Mr.'Dean died of typhoid fever in spite of all that could be done for him, and no lumber could be found suitable for a coffin. Finally, Mr. Weatherly, now one of our most successful land dealers, offered the side-boards of his emigrant wagon, and by the help of a carpenter a sarcophagus was made, not as lasting as the Egyptian Kings', but perhaps embalming more tears and sighs, for this funeral seems to have made a lasting impression upon the memories of the early pioneers.

Perhaps the most serious annoyance causing sickness among the people, was the lack of good wholesome bread.. A kind of a crude machine, that barely cracked two bushels of corn in a day's time, was built on Timber Creek by William Asher. The grit and dirt made the corn bread any thing but palatable. It was a hundred miles to Oskaloosa, and they were obliged to wait a week for the grist, and if the roads were bad and Skunk river impassable from high water, the result was, corn meal ground through a coffee mill, and made into "flap jacks." Mr. Alexander Boules, in 1849, got out of powder to kill game, the corn meal was scarce, and their bill of fare reads: Soup.-a la deer hide. Meats-

Vegetables_— Dessert.-Black haws. Coffee. -a la sassafras, the material of which they had bronght from Kentucky.

But we return to the projects which gave hope to the early settlers, that this state of things would pass away.

From 1853 to ' 56 the Fulton"Air Line R. R. was talked of, to pass through the county, making Marietta an eligible station on the line, thus bringing to the homesick emigrants the comforts of the East. The road was graded from Lyons westward 
forty miles, but "Gilpeck \& Co., of Dubuque, negotiated the bouds in Germany, and were fast controlling the stock, so when the Cedar' Rapids road was surveyed, interested parties got the Legislature to transfer the Fulton grant to the Cedar Rapids road, and this project of Gilpeck's was crushed like an egg shell. Anson and Rice determining that Marshalltown should not be a suburb of Marietta, restless and ambitious, had already commenced the contest to remove the county seat from the latter to the former place. Every artifice was resorted to to gain the result. Atwater, the Prosecuting Attorney of the county living in Marietta, was approached by these men to work professionally, and every other way for Marshalltown.

They gave him six lots in Marshalltown and a hundred and fifty dollars in money, and forthwith he commenced operations. VGriffiths, the county Judge, luckily resigned, and Atwater taking his place issued a mandamus from a petition, ordered the county records to be removed to Marshalltown, as at the time of the location at Marietta there were only two instead of three commissioners, as ordered by the State Legislature. Then three commissioners were appointed by Judge McKay, of Des Moines, to locate a new county seat. Anson and Rice treated these commissioners with wonderful hospitality, made them presents, and the stakes were set for a new city. Every new-cemer was treated with distinguished consideration, so that the "emigrant-ship" might unload its freight of chickens and little ones in the Marshalltown harbor. They were told that Marietta was the "last ditch," and that it was a "fiog pond," etc. The Supreme Court, howerer, to the great disgust of Anson and Rice, decided that the first action was legal by the original commissioners. Of course, this was denied by them, where men had no access to the newspapers, and petitions were circulated all over the county for a new election in $\mathbf{1 8 5 4}$, 


\section{CHAPTER IV.}

Marietta had recieved new accessions from the East. Hon. De Loss Arnold commenced practicing law, and among the enterprising men of that time were Thos. Abell, Esq., from Dunkirk, John Turner and Hon. H. E. J. Boardman. Bangor, Liberty, and all the western townships favored Marietta, as it was nearer the geographical center, while Albion, like a dog in the manger, favored neither, as she hoped to get it herself by some hocus pocus.

At the fall term of the Court in $185 \mathrm{~N}$ Jage "McFarland was on the bench. He was one of the queerest men that ever lived. He had a divorce suit, on hand at the term above mentioned, and both parties wanted divorce. The court opened in due form, parties present, etc. The first witness called was asked what he knew of the parties to the suit. "Oh! not much, they are slways a fuddling around," he answered.

At this MeFarland half roused himselt from a sleepy stupor. "Fuddling around, and around! Clerk, I grant a decree for divorce. Call the next case!" Thus summarily was justice meted out in the olden time.

One of the lawyers at this term of court was from Burlington, and was facetiously named by his professional brethren, "old Timber." He was submitting his case to the jury in fine rhetoric, when a large mule braying loudly, thrust its head through the Court House window. McFarland cried out, "Hold up Old Timber, this honorable court cannot entertain both of your opinions on this question at the same time!" Nothing could equal the intense disgust of " old Timber," for the effect on the jury was such he lost his case. But his loss was a great gain in fun to the whole multitude.

At another time $\mathrm{McF}$ arland was so drunk that he could hardly sit on the bench. Court was called in due form. Lawyers, jury and witnesses all waiting, when His Honor vacantly stared around. "Well! well! gentlemen, call this court together to-morrow morning at 8 o'clock," and walked 
off. There was no other way, only to wait for Justice to right herself.

In September, 1855, at that term an action was brought by Charles Brivnock, N. P. 'Gregg, counsel. In illustrating his. case the Latin quotation, "Ad quod Damnum," came in pretty often. and after the counsel for the defendant demurred, Gregg repeated the classical quotation. McFarland broke in, "Gregg, I am going to knock your case higher than a liberty pole. Get out of court with your $A d$ god damn 'em, and don't you ever use so much profanity in my presence again!" Gregg tried to bring a decision from the Suprome Court to sustain his case. "I don't care a d-n for the Supreme Court. Mr. Clerk cąll the next case," and the Judge leaned back with great dignity, perfectly oblivious of his ignorance.

${ }^{\vee}$ Marietta had a society that was called the Grand Coop of the Oriental Order of Bachelors, and as witty, genial set of men as ever drew around the board.

Hon. Thos. ${ }^{\vee}$ Mercer, Arnold, our graceful State Representative, Jeff Crookham and John'McRye were the leading spirits.

They debated, told stories, devoured nuts and candies, and seemed to exercise considerable social influence. They found the discipline of the Grand Coop rather bad for their digestion, for every one of them were noosed in matrimonial ties within three years. Mercer has filled many offices of trust through the war under the government. Crookham died near

$\checkmark$ Oskaloosa some years ago. Crookham was passionately devoted to the interests of Marietta, and when he was in Mar$\checkmark$ shalltown some of the citizens took delight in teasing him. One day Kelley and Hambel got a pareel of Hoozier emigrants withiu ear-shot of Crookhan, and told some terrible stories about Marietta. "Why, don't you think?" said Kelley, a man was drowned on their public square last week!" Grookham tried to explain matters, but Kelley told them that Crookham had lots to sell up there, and he would tell dreadful yarns. The consequence was a larger Hoosicr element in the population of Marshalltown. 
In the year of 1854 a settlement was made at French Grove by two brothers, John and Joseph Anselme, Frenchmen, who lived in log cabins, and being near a grove had plenty of timber to fence with. For a long time this settlement was the only one for thirty miles due westward from Marietta. They were jovial fellows, and hunters far and near made it headquarters. In Jefferson township William ${ }^{Y}$ Powers, and his brothers Isaac and John, came and settled in 1852. Here also was a rendezvous for hunters in an early day. George Wiles, with a party of five, went beyond this grove one day and killed three hundred and eleven chickens, returning to towntheir two horse wagon loaded with game, chickens' wings and heads festooning the sideboards of the same like fresco work.

A family by the name of Hoppin lived near the edge of the township; their nearest neighbor was three miles away. Mr. Hoppin was an inexperienced farmer, being by profession a book-keeper, but hearing wonderful stories of making money in the West had bought a farm and commenced operations. He put up a little cabin, raised sod corn, a few pumpkins and beans, and the cold winter found him unprepared for fuel and hay. He was obliged to go ten miles for wood. All winter he bravely bore up under his misfortunes, for his cattle died and children were sick, but in March he died of typhoid fever. The wife had nothing but parched corn for bread, and not a drop of tea oi coffee for eighteen months.

One cold day in October Mr. Jonathan ${ }^{1}$ Reed, from Ohio, left his wife and family out on the sea of brown grass about three miles from a house, sewing a tent cover as he started for VOskaloosa to bny flour. When the tent pins were adjusted it was fornd the cover would not fit the tent or wagon either, so they crawled under it and passed the night the best they could. One of the neighbors finally took pity upon their forlorn condition and rented to them a small, smoke honse twelve feet square, where the family (of eight persons in all) lived through the winter.

This summer was a period famous in Marshalltown for the 
"brick suits" between Wells"Rice and G. M. Woodbury. These suits were used by Marietta people to influence votes in favor of their town in the spring election upon the removal of the county seat. "See here!" said they, " those men must be rascals, or they would not fall out!" After this quarrel was adjusted, these prominent gentlemen let all private matters drop, and they worked together like beavers to get the records removed until 1860 , when there was no further cause for brotherly love. At the spring election in Marion township, Thos. VAbell, Esq., of Marietta, had a good many personal friends there. He bad lent money at a low rate of interest, and the rough farmers seemed to appreciate the favor. In the morning Mr. Abell was ready to bet the township would give Marietta a large majority. Wells Rice and some of the Marshalltown men were there, and about ten o'clock, Stewart, of Marion, reached out his arm in a threatening manner and said to Abell, "You sir, have been stealing the Marshall. town ballots, give them up!" Mr. Abell protested that he had not seen them, but so dumbfounded was he that he kept out of sight most of the time that day. The result of this scheme was, that Marion gave thirty majority for Marshalltown. Rice had the ballots in a safe place, and it was only an artifice to bully for votes. Abell told the writer of this article he never felt so mean in his life, and yet he knew that he'was innocent. The ${ }^{1}$ Marietta Express, however, placed a symbol bird at the head of its columns announcing victory for Marietta throughout the county. The Albion paper seemed to rage at this, and called out some terrible invectives in their columns, but it was of no use, Marietta had beaten her foes, and lot-holders in the persecuted city telt safe. Mr. ${ }^{\top}$ Crow, who kept the Marietta House, gave a fine supper to his friends. But a word of the moral influences have monlded society to its present condition of intelligence, morality, etc.

The Kethodist Episcopal Church as early as 1851 founded what was called, her Marshall Mission, Rev. S. Dunton doing the work. Late one night in the autumn of this year he 
reached the cabin of Mr. Ralls, on Linn Creck, south of the city of Marshall, chilled and hungry from his long ride on horse-back, coming through from Iow a City in two days.

After cheering a few friends in the vicinity with the first consolation that a minister of Christ could give in the sparse settlement, he attempted the next day to go onward to Mari- etta and form a class, but the high water prevented his crossing Linn Creek, for the torrent had loosed the only bridge, so he was obliged to return to Iowa City for a more favorable opportunity. The next spring he came back and organized a little church at a Mr. 'Griffiths at the mouth of Timber Creek. In $1853 \mathrm{a}$ church of this denomination was organized in Marshalltown at the school room in a house owned by Chris. Ford, but its progress was slow, and as late as 1857 it numbered only thirty members.

The quaint, yet pious Rev. Mr.'Shinn, who was once appointed temporary chaplain of the House of Representatives. His memorable prayer upon that occasion may be forgotten in history unless we reproduce it. "Great God! bless the young and growing State of Iowa, bless her Senators-her Representatires, bless all her state officers, give us a sound currency, pure water and undefiled religion for Christ's sake. Amen!" A model prayer, for it was brief. The first camp meeting was held in the forest near Griffith's mill at the mouth of Timber Creek. Here with no "rustling silks or jewels shine," old fashioned Methodism made itself felt far and near, and with a hearty remembrance of the enjoyment of this meeting it wrought out a great work in His vineyard, for it numbers through the county a membership of eight hundred.

The New School Presbyterian Church was organized in Marshalltown in 1858, with Rev. Mr. Gordon as pastor. There was only a little handful of members-nine in all. Mr. Gordon was a radical anti-slavery man, becoming quite unpopular with his congregation, and was obliged to leave after a pastorate of a year. He also preached in Albion, and occasionally in Marietta. 
The Rev. Mr. ${ }^{V}$ De I Loss was, however, the most efficient minister in the whole history of this church organization. He obtained subscriptions for a church, got men to give day's works upon the edifice, and after a while, after much labor and financial discouragements, the brave old man saw one of the finest church buildings in the State erected as a reward for his prayers and efforts. He died soon after his work was done, much lamented.

There was a Congregational Church organized at Ḿarietta and Albion in 1859, and the Rev. Mr. Boardman alternated his preaching in both towns. The Lutherans came to Albion in 1861, also had preaching in Marshalltown.

The Universalists for some years have been quite numerous in the county, and now Baptists, Congregationalists, ${ }^{1} \mathrm{Disci-}$ ples and Episcopalians are wealthy, influential denominations.

About the year 1857 in the strife among the lowns of this vicinity for notoriety, Albion, fearing that her efforts in favor of getting the county seat would be abortive, at last concluded to try her hand upon some institution of learning.

Upon a hint in the journal published by Chapin and Barnhart, of Albion, subseriptions were asked of Marietta and Marshalltown so that a college building could be at once commenced. It was also intimated to the rivals that the one which gave the highest subscription would get the most votes from Albion and Iowa township in the coming election. Subscription papers whisked around a good deal faster than a poor-box in both towns, so when the paper's were opened it was found that Marietta had given three thousand dollars, and not to be outdone Marshalltown gave a thousand more. Albion was now shelved to the joy of the "rivals," and commenced her present college building. Marshall County roted the sales of swamp lands within her jurisdiction, the money to be used in the college building and for the payment of teachers.

A creditable building was erected, and every thing went on 
swimmingly for the new institution, otherwise called the Marshall County High School. But from some defect in the school law these high schools did not receive help from the State, so that no permanent endowmert fund could be made, and after a year or two the school languished.

The Lutheran Synod then approached the Trustees with a proposition to buy the College building for their own particular sect, and their denomination being influential would moke it the best school in the State. The Synod was to give sixteen thousand dollars for it, but for impecunious reasons the money was not all paid over, and finally after a term of years TLos. Swearingen, Esq., obtained a judgment against the institution, and it is now under his control, although the Synod claim the stock.

The College, under the supervision of Prof.'Schaefer, was a great success, but some evil spirit ever since has troubled it with misfortune, so that it never has numbered over twenty students since. The war injured it somewhat, and the citizens of Albion have not given it the support it needed. The history of Western Colleges, like that of Western Cities, is a varying one.

(To be Continued.)

\section{PIONEERS OF MARION COUNTY.}

BY WM. M. DONNEL.

(Concluded from page 390.)

On the 28th of September, 1861, Henry Haspers, having purchased the office of the old Pella Gazette, commenced the pablication of a newspaper in the Holland language, called the Pella's Weeklulad (Weekly). This paper was, and is, in the interest of the Democratic party, and enjoyed a good patronage, 
Copyright of Annals of Iowa is the property of State of Iowa, by \& through the State Historical Society of Iowa and its content may not be copied or emailed to multiple sites or posted to a listserv without the copyright holder's express written permission. However, users may print, download, or email articles for individual use. 